\title{
Locating the Contributions of the African Diaspora in the Canadian Co-operative Sector
}

\author{
Caroline Shenaz Hossein, Associate Professor of Business \& Society, York University, Canada
}

\begin{abstract}
Despite Canada's legacy of co-operativism, Eurocentrism dominates thinking in the Canadian coop movement. This has resulted in the exclusion of racialized Canadians. Building on Jessica Gordon Nembhard's (2014) exposure of the historical fact of African Americans' alienation from their own cooperativism as well as the mainstream coop movement, I argue that Canadian co-operative studies are limited in their scope and fail to include the contributions of Black, Indigenous, and people of colour (BIPOC). I also argue that the discourses of the Anglo and Francophone experiences dominate the literature, with mainly white people narrating the Indigenous experience. Finally, I hold that the definition of co-operatives that we use in Canada should include informal as well as formal co-operatives. Guyanese economist C.Y. Thomas' (1974) work has influenced how Canadians engage in co-operative community economies. However, the preoccupation with formally registered co-operatives excludes many BIPOC Canadians. By only recounting stories about how Black people have failed to make co-operatives "successful" financially, the Canadian Movement has missed many stories of informal co-operatives that have been effective in what they set out to do. Expanding what we mean by co-operatives for the Canadian context will better capture the impact of co-operatives among BIPOC Canadians.
\end{abstract}

Caroline Shenaz Hossein is Associate Professor of Business \& Society in the Department of Social Science at York University in Toronto, Canada. She is the Founder of the Diverse Solidarity Economies (DiSE) Collective. She is the author of a multi-award winning book Politicized Microfinance: Money, power and violence in the Black Americas (University of Toronto Press, 2016); co-author of Business \& Society: A Critical Introduction (Zed, 2017) and editor of The Black Social Economy: Exploring community-based diverse markets (Palgrave Macmillan, 2018). Currently she is writing her solo authored book, The Black Banker Ladies: Vanguards of Mutual Aid and the Solidarity Economy to be published by the University of Toronto Press and has a co-edited a book with P.J., Christabell, Community economies in the Global South with Oxford University Press. She can be reached at Twitter @carolinehossein

Acknowledgements: I am grateful to Bev Mullings of Queen's University who took the time to work through my ideas on Blackness and co-operatives. Zoom chats with Renee Hatcher helped to frame my thinking on the topic. Jessica Gordon Nembhard gave this paper a thorough review at an early stage. All of this would not be possible without members of the DiSE Collective who keep me grounded: Sharon Wright Austin at Florida State University, Tiffany Willoughby-Herard at University of California-Irvine and Bipasha Baruah of Western University. The National Conference of Black Political Scientists (NCOBPS) has supported my work on Black co-operativism for many years by ensuring that I was able to organize panels on this topic as far back as 2010. My research assistants Megan Pearson, Ushnish Sengupta and Tatiane Reis were instrumental in carrying out a thorough literature review and surveying LinkedIn profiles to learn more about equity in Ontario's co-op sector. This project was supported by the Early Researcher Award funded by the Ontario provincial government to understand the role of Black Ontarians in cooperatives.

\section{Key words: Co-operatives, Mutual aid, ROSCAs, African diaspora, Underground railroad, Rochdale, ICA}

There are two ways one might learn about the potential value of using co-operatives. One, fondly followed by generations of co-operative enthusiasts, is to start with some history, to retrace the steps in the development of co-operatives from their beginnings-usually starting with the Rochdale Pioneers in the 1840s in England-and then to follow the course of the development of co-operatives to the present day. This can be a useful route, particularly for those whose ancestry extends back to the industrial revolutions in the North Atlantic world. It is not so useful for others whose traditions embrace different value systems and whose 
histories are not so immediately shaped by industrialism. (Hammond Ketilson and MacPherson 2001, p. 3)

\section{Introduction}

Co-operatives are part of Canadian DNA, reflected in Canada's well-known legacy of co-operativism. Most literature about co-operative economics and co-op history is anchored in Eurocentric ideas and knowledge. In the opening quote to this essay, Canada's leading co-operative scholars Lou Hammond Ketilson and the late Ian MacPherson (2001) attest that the story of co-operativism in Canada is based on the European history of the Rochdale weaversa history that is not inclusive of people from different heritages. Rita Rhodes, author of Empire and Co-operation (2012), contends that the Eurocentric focus of the co-op movement excluded other people.

This essay builds on Collective Courage (Gordon Nembhard, 2014) which exposes the historical fact that African Americans have often been alienated from the mainstream co-op movement as well as their own co-operativism. I argue that Canadian co-operative literature is also limited in its scope and fails to include how Canadians who are Black, Indigenous, and people of colour (BIPOC) ${ }^{1}$ have contributed to the development of co-operativism. I also argue that the discourses of the Anglo and Francophone experiences dominate the literature, and that mainly white Canadians narrate the Indigenous experience. I also hold that the definition of co-operatives we use in Canada should include both informal and formal co-operatives. The work of African Guyanese economist C.Y. Thomas (1974) has influenced the Canadian mindset in how to engage in co-operative community economies. However, the preoccupation with formally registered co-operatives excludes many BIPOC Canadians.

According to the International Co-operative Alliance (ICA) website, co-operatives are collective, member-owned institutions organized by groups of people who are filling a gap in society and business. The current understanding of co-operatives, while applicable to any group using solidarity and self-help to address market failure, ignores and omits the contributions of non-Europeans. It is thus limited in terms of its relevance to a diverse group of Canadians. Though dated, the Canadian Co-operative Association produced a report (2011) on Ethnocultural and Immigrant Co-operatives in Canada that surveyed formal co-operatives among immigrants in English-speaking Canada. This preoccupation with formally registered co-operatives has led to the exclusion of many Black and racialized Canadians who have established co-operatives and collectives that are not formalized. In the United States, Gordon Nembhard (2014) has similarly found that to understand the traditions and legacies of solidarity, mutual aid, and co-operativism among BIPOC Americans, it is important to study diverse examples of economic co-operation, not just formally incorporated co-operative businesses. In the Caribbean context, Hossein (2017a and 2017b) also notes the importance of studying both the informal and formal Black social and solidarity economy in order to understand not just economic survival but also financial co-operation and political control. The mainstream North American literature on co-operatives at best marginalizes and usually ignores the purposefully informal co-operatives that BIPOC people engage in. Furthermore, nowhere does the literature address why this is the case. In fact, co-operative literature largely misses counting informal co-operatives as part of the ecosystem.

Formal and more established co-operatives for the most part have not been helpful to Blacks in their efforts to set up co-operatives in Canada. The Canadian movement only recounts stories about how Black people have failed to make co-operatives "successful" financially, in this way missing many stories of co-operatives, most of them informal, that have been effective in what they set out to do. We need to expand what we mean by co-operatives in the Canadian context to include the BIPOC perspective. This definition, if it included Black and racialized people, would include more co-operators who are non-white and would push for Black and immigrant peoples' voices in what a co-operative should be.

Co-operatives are voluntary organizations usually born out of a crisis. They often exist to fill a need in business and society (see ICA, n.d.; Gordon Nembhard, 2008, 2014). These organizations are democratic, and rules are determined by the members who created them (see ICA, n.d.). The more we study co-operatives and solidarity economies, the clearer it becomes that people around the world have and are engaged in formal and informal co-operatives. One of the most impressive co-operative movements in the world, for example, is taking place in the state of Kerala, India: despite a tense political climate, millions of women come together in the Kudumbashree movement to protest oppression and to help each other in all facets of life (Thiagarajan, 2019; Christabell, 2013). 
Globally, more than 1.2 billion people belong to co-operatives. Many co-operatives are also informal and grassroots groups. The ICA (n.d.) has defined co-operatives as:

people-centred enterprises owned, controlled and run by and for their members to realise their common economic, social, and cultural needs and aspirations. Cooperatives bring people together in a democratic and equal way. Whether the members are the customers, employees, users or residents, cooperatives are democratically managed by the 'one member, one vote' rule.

This definition, along with the seven internationally agreed co-operative principles, suggests that these groups should be spreading the co-operative movement, which does not deny anyone based on identity and race. To better capture the importance and impact of co-operatives among a variety of communities and peoples in Canada, our definition of co-operatives should include informal and formal co-operatives carried out by Black and racialized people. This would better represent the sector and recognize the myriad forms and players. In addition, as part of the sixth principle of co-ops-co-operation among co-operatives - the onus should be on established co-ops to assist in the development of co-operatives organized by people of colour.

\section{Reckoning with what co-operatives should be}

Co-operatives are truly international-practised around the globe. It is not clear where the idea of collectively organizing with the intention to help others originated. Nici Nelson (1996) documents banking co-ops among Kenyans since the 1970s and believes that this activity began well before the colonial time. In carrying out research in Bahir Dar, Ethiopia, in the fall of 2018, academics and leaders in community development explained that the Habesha people were the first in the world to create the idea of collectivity by way of Equub and Indir and lqib, which are informal group systems of credit and savings (Bekerie, 2003; 2008; Kedir \& Ibrahim, 2011). Given that Abyssinia (today Ethiopia) is revered as the land of human origins, this theory may be plausible. India also has an ancient system of Chits, that help people access funds through a group methodology. Laws regulating Chit funds date back to the 1800s, and people organized these systems long before colonization (Sethi, 1996; Datta, 2000). In fact, India leads the world in the number of co-operatives, and the very first meeting for the ICA was held in India to mark this achievement (Williams, 2007).

It is difficult to pinpoint the origins of co-operative development. Co-operative historian Richard C. Williams (2007) has found that some of the earliest forms come from the Global South, in places like India and China where collectives were everywhere in developing the society. Thomas Davies (2018), in his exploration of the historical development of non-governmental organizations (NGOs), argues that the world's NGOs and community organizations were first created outside of the Western world. Chancellor Williams (1993[1967]) has argued that "the economic basis of African life was originally co-operative" (p. 151). These views, however, are rarely acknowledged in scholarly writings about co-operatives.

Instead "original" co-operative movements are noted to be in a European context. Some of the earliest of these are fire insurance mutuals in the UK; a number of cheese co-operatives out of France; and Robert Owens' experiment of the New Lanark in Scotland-all of them envisioning systems of co-operatives to counteract corporatization. Lanark ran into troubles over mismanagement, but this is seldom discussed (Williams, 1993[1967]). The ICA (n.d.) has shared that the Rochdale co-operative in 1844 was the founder of the co-operative principles, and the modern co-operative movement has been memorialized by this historical fact since ICA was founded in 1895. This homage to Rochdale continues even though Rochdale became a commercial firm at one point and experienced sustainability issues (BBC, 1980; Williams, 2007).

Ideas of being co-operative are larger than Rochdale. The theory of community economies by J.K Gibson-Graham (2006; 2003; 1996) and the Community Economies Research Network (CERN) have shown diverse forms of cooperation in the Global South, outside of the politics of capitalist and non-capitalist binaries. A CERN member and solidarity economy scholar Ethan Miller (2010) attributes the concept of economia solidaria to peoples' movements in Latin America, specifically Peru, Chile, and Brazil, where BIPOC people have protested against their unequal treatment by the colonizing white elites. 
In Canada, Indigenous people have potlatches and Wisdom Circles as ways to rethink co-operativism (Wuttunee, 2010). In the United States, W.E.B. Du Bois (1907) referred to the Underground Railroad of the 1790-1800s as a co-operative movement, where people made both economic and social commitments to risk their lives to move enslaved people into freedom. ${ }^{2}$ Du Bois documented many examples of AfricanAmerican mutual aid and cooperativism (Haynes, 2019). John Curl (2012, p. 4) concludes that, in the U.S., "the history documents how cooperatives were an integral part of numerous American communities in many time periods, and how the working people of this country turned time and again to cooperation for both personal liberation and as a strategy for achieving larger social goals" starting in the 1830s. Not only does Curl (2012) include Black mutual aid and co-operative action in this history, but he also recognizes that the first North Americans "to practice collectivity, co-operation and communalism were, of course, Indigenous... Cultural patterns of economic co-operation were clearly engrained in the fabric of every tribe" (p. 15). He provides early examples of economic co-operation from First Nations, including the Shoshone Nation, the Lakota, Southwest Pueblos, Northwest Coast tribes, and the Iroquois Confederacy. Wanda Wuttunee's foundational work (2010) shows the importance of various collective systems and how people considered the environment, their livelihoods, and their own spirituality in thinking through opportunities.

Millions of people around the globe participate in informal co-operatives to access financial services and consumer goods. It is the informal nature of how these groups operate that makes them so important to ensuring collectivity and reaching those people most excluded in society. Omissions of informal co-operatives in research are unnecessary and counterproductive.

\section{Remembering C.Y. Thomas' economic theories for community-based self-help ${ }^{3}$}

It is plausible that African peoples' collective and co-operative systems predate most systems in the world (see Williams, 1993[1967]). In the United States, Gordon Nembhard (2014) chronicles the many forms and practices of African American co-operativism, as well as the impact of Black mutual aid and communalism on the larger U.S. community development movement (Haynes, 2019; 2010; Stewart, 1984; Sullivan, 1969). In Canada, Black Canadians' descendants from Africa have been giving to Canada for a very long time. In the 1700s, for example, an African interpreter for Europeans by the name of Mathieu de Costa brought knowledge and ideas about how to trade with the Indigenous people of Canada (Johnston, 2001). Black Canadians, however, are still seen as newcomers. While history reveals otherwise, Black arrivants ${ }^{4}$ to Canada are often missing in the literature and storytelling of Canada's settler experience (James et al., 2010). Indeed, Black Canadians are often viewed as recent migrants. Ryerson's Grace Galabuzi (2006) has found that contemporary immigration policy in Canada is biased against BIPOC applicants, a situation that has existed for decades. Even though policy has diversified the groups of people emigrating to Canada, the integration of Black immigrants into the Canadian economy has been especially difficult.

Guyanese economist C.Y. Thomas (1974; 1988), in his research on small Caribbean countries, explains how smallsized economies like Guyana can outwit the World System created by Europeans focused on the extraction of their precious raw materials from the Caribbean and leaving the local people dependent on imported food stuff. ${ }^{5}$ The Caribbean people's focus on what they need and their investment in their own self-sufficiency has had an impact on local economic co-operation in Canada and elsewhere. Thomas' (1974) body of work is important because it speaks to self-sufficiency and economic co-operation, which has always made sense to the Caribbean diaspora. Thomas' (1974) work has influenced Canadian community economic development, making it clear that Black perspectives have shaped Canadian ideas on how to collectively organize economic goods (Rebel Sky Media, 2018). The late Canadian economist John Loxley $(1985 ; 2008)$ credited Thomas' work as the basis for the Neechi principles that drive how organizations engage in their own self-help and sufficiency in the economy. It is significant that an AfroGuyanese scholar has influenced the very principles we use in community economic development in Canada and that are endorsed by the Canadian Community Economic Development Network.

\section{Valuing the informal}

The co-operative sector has missed the opportunity to help BIPOC people build their own co-operatives. Co-operatives in Canada follow ICA's definition and are formally registered by the provincial government. This means 
that only institutions that meet ICA criteria are considered co-operatives. However, in the province of Ontario-and most likely across Canada-many forms of co-operative that operate informally do not fit into this definition. To understand the co-operative experience as it relates to the African diaspora and racialized minorities in Canada, we must expand the definition of co-operatives to include institutions that are voluntarily formed by groups of people, usually from the same socio-economic group, who come together because they are excluded from mainstream business.

Co-operatives are very important to democratizing the market; however, they are in gradual decline, especially in the Global North according to Richard C. Williams $(2007 ; 2010)$. In contrast, in the Global South, co-operatives are pervasive, embedded into people's ways of life; but because of their informal nature, they are often relegated to the sidelines. In Canada, formal co-operatives are mostly led by white people and these institutions have limited appeal to racialized people. Cities such as Toronto and Montreal have large numbers of BIPOC, and co-ops miss an opportunity to reach these groups. Many Black and diaspora people emigrate from places where co-operatives and credit unions are well-known and they bring added knowledge about self-help groups, collectives, mutual aid, and rotating savings and credit associations (ROSCAs)-all forms of co-operativism.

Making co-operatives inclusive of BIPOC contributions would be a start in undoing the whiteness within the sector and hiring leaders reflective of society. As stated earlier, I argue that co-op knowledge in Canada is anchored in European concepts, failing to acknowledge BIPOC Canadians' deliberate use of informal co-operatives. In this paper, I critically analyze the three main discourses for co-operativism and introduce the Black Social Economy as an epistemology that is explicit in its use of informal co-operatives as a way to diversify the co-operative movement.

\section{Methods and approaches}

Over the years I have published a number of articles on the African diaspora and Black origins in the social economy. In the course of my community work, it became clear that the literature, specifically the question of who is a co-operator, needed attention. In Canada, research defaults to Western (read white) ideas about co-operatives as a given, without acknowledging BIPOC contributions in this sector. Teaching these literatures made me complicit in furthering this knowledge. I became acutely aware of the need to write a paper that challenges what we mean by a co-operator in Canada. It is also imperative to push the sector as a whole to be inclusive of the kinds of co-operatives Black and racialized people take part in in Canada.

For the past nine years, I have examined and thought about informal co-operative banking groups among the African diaspora in Canada and the Caribbean. My interest in Black co-operatives was piqued first while a doctoral student in Jamaica in 2008 and again on a trip to Accra, Ghana, where I met Jamaican immigrants in Ghana using the Marcus Garvey Credit union. In our exchange, they inquired about Black co-operatives and credit unions in Canada, but we had none. From that day on, I started to view ROSCAs and similar organizations as co-operatives and wondered why they were not included in the formal definition of co-operatives. Much of this paper is informed by my years examining immigrant and Black co-operatives and mutual aid groups (Hossein, 2015). The more I study these informal co-op groups run by racialized women, the more convinced I am that they should be considered co-operatives and that immigrants do not "lack knowledge" about these systems. Over the years, I collected papers and documented writings on co-operatives and saved stories from newspapers on co-operatives run by the African diaspora.

My research assistants, all advanced doctoral students, carried out a sweep of the co-operative material in the field with an eye on those writings in Canada. They located obscure sources and formulated a list of Ontario credit unions, and also looked at a number of boards of well-known co-operatives in Ontario. Most of the credit unions on the list-such as Equity, Meridian, Alterna, and Ganaraska-serve the general public, and a few have affinities with groups such as teachers, health care workers, local trade unions, and firefighters. They all seemed to be lacking in culturally diverse leadership at the executive levels and within their boards. To learn more about these organizations, one of my research assistants carried out detailed searches of the boards of directors on Linkedln, reviewed feminist archives for Black Canadians and examined Twitter feeds. 
This work questions the general thinking that the African diaspora in Canada are not co-operators and do not know much about co-operatives. Gordon Nembhard's work (2014) was alone in reacting against the dominant view that African Americans were not co-operators; and a similar situation exists in the Canadian context, where the assumption is that Blacks and immigrants are not informed about co-operatives. Lived experience and informal co-operative expertise are not acknowledged as valid.

\section{Grounding the BIPOC co-operator experience in Canada}

The story of co-operatives in the Canadian context is often told from a Eurocentric perspective, ignoring the Black and Indigenous experience. These two groups suffer some of the lowest scores in human development in Canada and in many other places (Timothy, 2018; National Council of Welfare Reports, n.d.; James et al., 2010). What is absent from Canada is theoretical framing and knowledge-making in the study of the co-operative activities of racialized people.

Notably, recognition of different forms of co-operatives is the norm outside of Canada. A recent International Labour Organization (ILO) webinar on gender equality and co-operatives, which hosted more than 175 people, made it clear that co-operatives include informal organizations like ROSCAs (27 April 2020). The Self-employment Women's Association (SEWA) presented expertise in building informal and formal co-operatives, each having a place in Indian society. In Canada, Indigenous scholar Wanda Wuttunee (2010) has located her own lived experience as well as firsthand knowledge about Indigenous co-operative businesses, which can be both formal and informal. My studies $(2013 ; 2018)$ involved extensive empirical work in the Global South and Canada to understand financial co-operatives among the Black diaspora. Gordon Nembhard, in tracing informal and formal co-operatives in the United States, has argued that they are all part of the co-operative system. What is evident is that there is a gap in understanding Black and racialized peoples' co-operative expertise in the West.

The literature review in this paper emphasizes the ways that Black and racialized people are engaged in the co-operative sector. It seems an erasure exists within the co-operative sector of what racialized people have done in building co-operatives. In Rethinking Co-operatives: Japanese-Canadian Fishing Co-operatives, Jo-Anne Lee et al. (2017) argue, "This privileging of dominant group co-operative experiences has resulted in an impoverished understanding of ethnic minority co-operatives and of co-operative development more generally" (p. 541). The general sentiment has been that the sector is "pale, male and stale" and no effort is being made to change co-operatives. Yet a decline in membership (and the struggle to attract members) points to a need to rethink co-operativism for racialized groups.

As noted above, co-operatives are defined as open and democratic structures that aim to fill a gap and meet the needs of people who are excluded from mainstream business. A fundamental role of a co-op is to help other co-ops develop and to spread the movement. Canadian Desjardins International has an international arm focused on growing the co-operative movement in the South. Yet co-operative building in Canada is limited in how it invests in and helps minorities in their co-operatives. Beyond the scope of this paper is the separate issue that co-ops themselves lack cultural diversity in terms of race and ethnicity.

Boards on co-operatives are not always equitable-a situation that exists in Canada as well as in the United States. In a New York Times article, entitled “As Co-ops Spread, Discrimination Concerns Grow," Iver Peterson (1990) writes about the racist behaviour of co-operative boards in Brooklyn and Queens. The film Shift Change: Putting Democracy to Work (Dworkin and Young, 2012) shows how the membership in U.S. worker co-ops such as Evergreen are culturally diverse. African Americans and immigrants who are aiming for urban revitalization and community economic development are creating worker co-ops (Palmer, 2019; Hatcher, 2018; Haynes, 2010; Haynes and Gordon Nembhard, 1999). University of Illinois at Chicago scholar Stacey Sutton (2019) notes that Evergreen Ohio, embedded in racialized communities, is spreading from city to city as municipal leaders understand the cause.

U.S. scholars Wei Li and Lucia Lo (2008) also find that when commercial banks cannot meet the needs of the minority business community because of racial bias, perhaps credit unions can, and show that LA has over 30 ethnic banks from which to choose. By contrast, Toronto has 18 credit unions of which the majority are European (see Table 1). 
Other factors-including differences in national financial structures, immigration policies, and immigrant profilescontribute to the disparities in financial services for ethnic immigrants between the two cities.

A number of associations such as the Canadian Co-operative Association and Canadian Worker Co-operative Federation have tended to focus on formal co-operatives and we do not see large numbers of immigrants leading formalized co-operatives. However, BIPOC Canadians are forming co-operatives that tend to be informal ones, and the co-op sector is at a loss how to include them. Lou Hammond Ketilson (2006), found there is a need to expand the definition of co-operative, clearly stating that "the culture of co-operatives stagnated as the co-ops paid too little attention to education and efforts to attract young people and immigrants" (p. 3). The co-operative movement in Canada is missing the contributions of racialized people-the "minorities" - and much of this has to do with ignoring informal variants of co-operativism.

\section{Understanding the discourses of co-operatives in Canada}

The history of co-operative development follows theories that are Eurocentric and reflect the English and FrenchCanadian experience. Knowledge is grounded in theories that reflect a white settler experience of both white protestants and French Canadians. The third discourse is Indigenous-and it has been mainly narrated by white Canadians.

\section{The English Protestant discourse}

The dominant discourse about co-operatives stems from the English Protestant telling of these stories (Fairbairn, 1994). The ICA (n.d.) names the Rochdale co-operatives that began in 1844 in England as the prototype for co-operatives (see Photo 1 ).

Photo 1: The Rochdale Pioneers, England

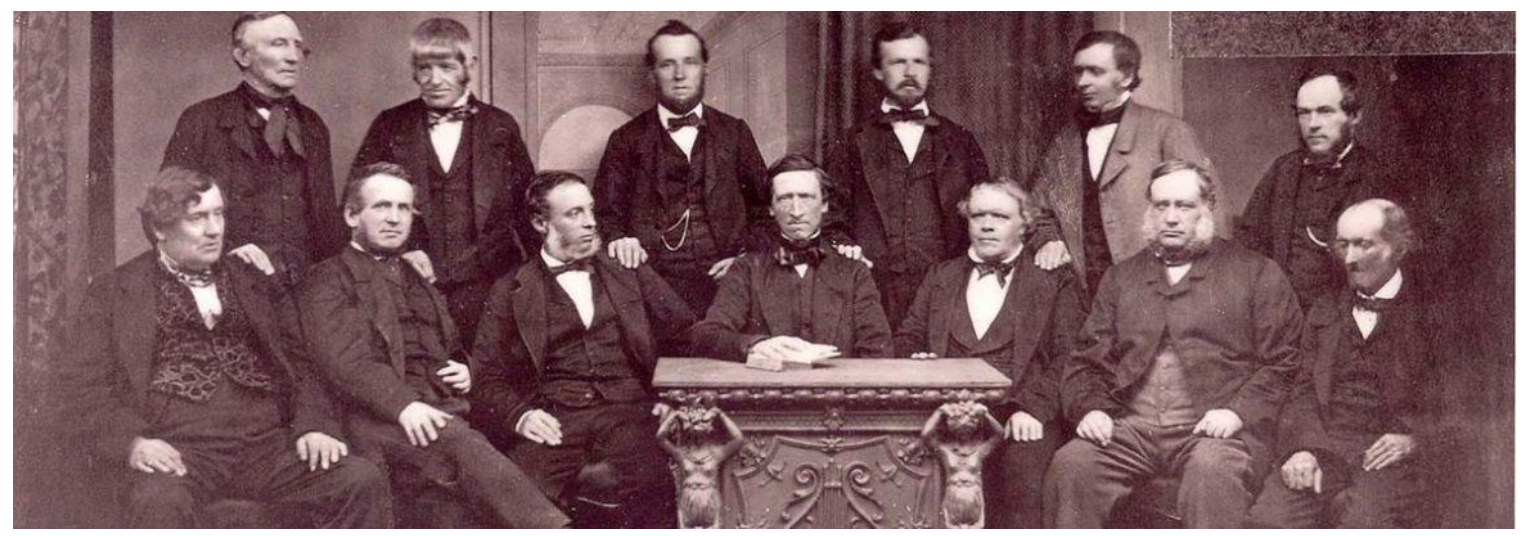

Source: ICA website (6 May 2020)

The Reiffeissen worker banks of Germany are also referenced for the credit union model and its ability to address financial exclusion (Guinnane, 2001). The ICA names the Fenwick Weavers' society in 1761 as the first co-operative, through which the people of Scotland sold basic food stuff as a way to bypass commercial factories.

On its main web page, the ICA notes that many co-operatives started off as "small grassroots organisations." However, only industrialized regions of the world such as Western Europe, North America, and Japan are sourced as points of origin for these organizations. English Canada's ideas dominate the learning about co-operatives in Canada. The Guelph Campus Co-op, founded in 1913, is featured prominently by the Ontario Co-operative Association (OCA) as part of the origin story of the co-operative movement in Canada (OCA website; Wade et al., 1984, p. 16). In his book, One Path to Co-operative Studies: A Selection of Papers and Presentations, lan MacPherson (2007) documents that the first co-operative store was opened in Stellarton, Nova Scotia in 1861 (p. 32). But Gordon Nembhard's (2014) work finds that the first communal co-ops in Canada were the self-sustaining Black farms in Wilberforce, Ontario, as early as 1831 (p. 34). 
By far the most renowned co-operative legacy for English-speaking Canada has been the Antigonish movement in Nova Scotia in the 1930s. This co-operative movement was led by two Catholic priests, Reverend Dr. Moses Coady and Reverend Jimmy Tompkins, who drew on Catholic Social Teaching to develop agricultural extension services and adult education. Their intentions were to raise the consciousness of the fisher folk so that they could protest commercialization of the fisheries (Macaulay, 2002, p. 46; Welton, 2003, p. 80). This was a working class struggle: the documentary film, Yes You Can Do It: The Story of the Antigonish Movement, reveals that fisher folk wanted fair prices for their goods and financial services that served community needs (Murphy, 2009). While the film fails to include the minority experience in Canada, missing an opportunity to include knowledge of BIPOC Canadians in co-operatives, it does include the Ethiopian co-operative Just Coffee and connects it to the legacy of the Antigonish movement.

Western Canada, and particularly the prairie provinces of Manitoba and Saskatchewan, saw a similar struggle for the working class that resulted in the development of agricultural and farming co-operatives (Fairbairn, 2009; 2007; 2004; 2005). Since 1896, Wawanesa Mutual in Winnipeg, Manitoba has been rooted in co-operation to meet the insurance needs of farmers ("History of Wawanesa", 2020). Co-operatives of white Europeans from the 1930s focused on the issue of the commercialization of food, principally in the wheat and fisheries sectors. These are very important struggles for the white working class. This English-speaking trajectory is framed in a very white and exclusionary narrative.

\section{The French discourse of the economie sociale}

Another prominent narrative of Canadian co-operativism is the French-Canadian economie sociale experience in the province of Quebec. The struggle of class politics also preoccupies the social economy, and as in English Canada, racial bias is ignored in this discourse.

Historically, the 1900 Desjardins caisses populaires movement dominates the understanding of Quebec's social economy (Mendell, 2009a, 2009b; Lévesque et al., 1997). The 1990s saw wide-scale support for the development of the Chantier de l'economie sociale, a provincial trust fund that received substantive funding of more than fifty million dollars toward co-operative and social economy development. Desjardins is revered globally as a leading co-operative in the world. In 1900 Alphonse and his wife Dorimene Desjardins learned about the German worker co-operatives established by Friederich Reifeissen and Hermann Schulze-Delitzsch and believed a caisse populaire (credit union) would meet the needs of a French-speaking minority in Quebec (Mendell, 2009a; 2009b). Benoît Lévesque et al. (1997) describe the integral connections between the socio-economic development of French Quebec and the growth of the Desjardins movement to become the primary financial institution and largest employer in the province of Quebec (p. 494).

Desjardins has an international arm that carries out technical assistance in developing countries to strengthen the co-operative sector. When doing doctoral research in Haiti in the early 2000s, for example, I observed that Desjardins was hired as the technical provider to assist the local network, Le Levier, following a scandal there. Desjardins also invests in environmental sustainability and social innovation within Canada (Vezina et al., 2017, p. 265); however, in order to work with immigrant Canadians in Quebec, the organization has had to call on its international arm working in developing countries.

I found it interesting that - the international staff understood cultural diversity and were better trained to work with allophones and Black minorities living in Quebec than the Canadian-based staff (Focus groups, Little Burgundy and Cote des Neiges, Montreal, 2016). As I learned through interviews by a partner funded by Desjardins, this is in part due to staff being unable to connect to non-white people including Haitians, Quebec's largest Black community (Interview with a partner organization of Desjardins, name and location withheld on purpose, 2016). In the eyes of BIPOC Canadians, Desjardins seems too white and is an institution whose employees are mostly concerned with "Pure Laine" - white French-speaking people. And so, while the Desjardins caisses populaires have addressed the needs of a distinct minority of French Canadians, they have had limited impact on BIPOC and non-French minorities. 


\section{The Indigenous discourse on co-operativism in Canada}

The third and final discussion of the history of co-operatives in Canada has focused on the Indigenous experience. It should be said that the research space on Indigeneity and co-operatives has been dominated by white men and nonindigenous people who do not have first-hand experience of what it means to be Indigenous. Hammond Ketilson and MacPherson (2001) have written extensively on Indigenous co-operatives, noting that these organizations have been used both as part of the colonization process by the state and as a form of business for self-determination. Hammond Ketilson and MacPherson's work can be viewed as distinct from the Eurocentric co-operative trajectories, as they take up how the colonial and settler experience impacted and continues to impact Indigenous livelihoods, cultures, and practices that may not adhere to Western conceptions of development. In this, they address the harmful histories of colonialism, in part through a narrative of the purposeful underdevelopment of a people, and explore why co-operatives are vital to Indigenous populations.

Co-operatives in Indigenous communities in Canada range widely. Some economic developments in Indigenous communities have been strongly associated with the development of co-operatives (Dana, 2010; Anderson, 1999); but more critical analyses have also emerged of Indigenous co-operatives in the context of colonization (Quiring, 2006; Sengupta, 2015; Quarter et al., 2017). Chris Southcott and Valerie Walker (2015) carried out a massive study examining the social economy in the hinterlands among Aboriginal people. Hammond Ketilson (2006) outlines the varied forms of co-operativism among Indigenous populations. Citing differing and conflicting values of membership, she stresses the need to understand and identify variations in models of co-operation among Indigenous people.

While European perspectives describing Indigenous co-operatives have been insightful, the work rarely draws on Aboriginal theories. For example, El Bachir Abdelouahid Belhadji (2001) takes a quantitative approach to making sense of Canadian co-operative data, noting a number of statistical differences between Northern and Southern Indigenous co-operatives, as well as between Indigenous and non-Indigenous co-operatives. Sectoral distributions, membership, and profits can be informative, but such findings are limited in terms of a holistic understanding of co-operatives in culturally diverse Indigenous communities. Such limited understanding perpetuates a singular view of co-operatives, maintaining a dichotomy between "regular" and "Aboriginal" co-operatives.

Isobel M. Findlay (2006) takes a more holistic approach in Putting Co-operative Principles into Practice. Lessons Learned from Canada's North. She argues that Inuit co-operatives guided by local knowledge were rooted in economic co-operation with the main goal of fighting against systemic exclusion. More specifically, they aimed to protect the Inuit people's connection to the land. University of Saskatchewan scholar Brett Fairbairn's (2004) work reveals the deliberate colonial project to contain Indigenous people, which was evident in the set-up of the first co-operatives:

Co-ops emerged as part of colonialism in North America-they emerged as European Institutions and as tools for Europeans to establish themselves as settlers in a world that was new to them. Co-ops did not exist (until much later) for the benefit of the Aboriginal population (which was immensely reduced by disease, devastated, and swept aside), but, rather, for the colonists. More specifically, co-ops were a response to tensions and problems in the colonial economy that became more apparent as it underwent industrialization. (p. 27)

Bias against and management of Indigenous people were initially perpetrated through co-operatives. But Fairbairn (2009) also notes that these co-operatives can be a vehicle for people to come together and repair the damage done to them.

Other studies of Indigenous co-operatives in Canada-such as Gibson et al., (2005) - locate the Aboriginal experience in the co-op sector. Edith Iglauer's (2000) work on Inuit, Doug Lionais and MA student Kim Hardy's work (2015) in the Yukon, and Aliva Tulugak and Peter Murdoch's (2007) work on co-operatives in northern Quebec have revealed an expertise in co-operativism among Indigenous people and suggested that there is much room for Indigenous people to tell these stories themselves. Wuttunee (1992), for example, does a good job of making space for and telling the story of the "Ikaluktutiak Co-operative Limited, Cambridge Bay, NWT" through an Indigenous perspective. 
Case studies are useful tools in organizing and understanding information and knowledge about how co-operatives operate among Indigenous peoples. The Canadian Community Economic Development Network's archives contain cases on the Great Bear Co-op and Neechi Foods (Findlay \& Wuttunee, 2007); the Neechi Foods Co-operative (Rebel Sky Media, 2018; Grant, et al., 2018; Loxley, 2002); the Northern Saskatchewan fisheries co-operatives and Buffalo Narrows Sawmill Co-operative (Quiring, 2006); the Northern Saskatchewan Trappers Association Co-operative (Pattison, 2010); prison co-operatives (Harris \& McLeod Rogers, 2014); and Inuit co-operatives (Stopp, 2014). These cases open up our knowledge of co-operatives formed by non-white Canadians. And yet, Ian MacPherson's (2012) warning eight years ago still rings true: that regionally the northern Canadian experience and Indigenous co-operative movements are and continue to be largely under-researched (p. 76).

Cliff Atleo (2015) is a Tsimshian (Kitsumkalum/Kitselas) and Nuu-chah-nulth (Ahousaht) scholar at Simon Fraser University. He argues that capitalism cannot be Aboriginalized because of its fundamentally different world views. Wuttunee (2010) has also filled a gap in co-operative research through her book Living Rhythms, in which she acknowledges varieties of social economy organizations that cannot be homogenized because of the various cultures within Aboriginal groups. Sengupta (2015) has contributed to this conversation by recognizing that culture is a valued goal in economic co-operatives. And finally, MBA graduate Carole Anne Hilton has launched the Indigenomics Institute, focused on supporting Indigenous-run business in its various forms.

Arctic Co-operatives Limited, a federation of co-operatives that has incubated co-operatives and Indigenous-owned enterprises in Northern Canada, is held up in particular as a successful co-operative development in Indigenous communities (Quarter et al., 2017; Mitchell, 1996). In the 2018 film, The Inclusive Economy: Stories of CED in Manitoba, Louise Champagne, president of Neechi Food Co-operative, insists that tribal band economies are about caring about people and meeting people's needs. She argues that this was what Neechi Commons is bringing to the Point Douglas neighbourhood in Winnipeg (Rebel Sky Media, 2018). This illustrates that Indigenous people have always had a co-operative economic system that counted on humans first. The principles governing community economic development that the co-operative developed, and which are rooted in the idea of self-sufficiency, are known as the Neechi principles.

Subsidies from the Government of Canada to build Indigenous co-ops like Arctic Co-operatives Limited were seemingly accompanied by state agendas to settle previously nomadic Indigenous communities and establish Arctic territorial control and sovereignty through population settlement (Hammond Ketilson, 2006; Mitchell, 1996). This is an important finding because it shows that co-operative networks like Arctic Co-operatives Limited were able to sustain long-term government investment and technical assistance. The idea of remaking community economic development in Canada for Indigenous people is also rooted in ideas of the Black diaspora throughthe influence of C.Y Thomas' self-sufficiency, local needs and convergence theory.

\section{An erasure of the Black Canadian discourse in co-operativism}

Yet the contributions of BIPOC Canadians in the co-operative sector are missing and the discourse is predominantly white. Silent Transformation, a documentary by Brothers et al. (2017), in its quest to showcase the Ontario cooperative model for the good of society, anchored the academic knowledge and expertise as white and male. Knowledge making on co-ops has a white gaze in terms of how co-operativism is carried out and this favours white immigrants to be able to create their own co-operatives (see Table 1 below). The Financial Services Regulatory Authority of Ontario (FSRA) (formerly the Financial Services Commission of Ontario) has published a list of credit unions in Ontario that shows that out of 66 credit unions, only 12 are immigrant credit unions and most of these are white. 
Table 1: Ethnic Credit Unions in Ontario, Financial Services Regulatory Authority of Ontario

\begin{tabular}{|c|c|}
\hline European Credit Unions & Racialized Credit Unions \\
\hline $\begin{array}{l}\text { 1. Buduchnist Credit Union Limited } \\
\text { (Ukrainian) }\end{array}$ & $\begin{array}{l}\text { 1. Korean Catholic Church Credit Union } \\
\text { Limited }\end{array}$ \\
\hline $\begin{array}{l}\text { 2. DUCA Financial Services Credit Union Ltd. } \\
\text { (Dutch) }\end{array}$ & 2. Korean (Toronto) Credit Union Limited \\
\hline 3. $\quad$ Finnish Credit Union Limited & $\begin{array}{l}\text { 3. Taiwanese-Canadian Toronto Credit Union } \\
\text { Limited }\end{array}$ \\
\hline $\begin{array}{l}\text { 4. Italian Canadian Savings \& Credit Union } \\
\text { Limited }\end{array}$ & \\
\hline $\begin{array}{l}\text { 5. Moya Financial Credit Union Limited } \\
\text { (Slovenian) }\end{array}$ & \\
\hline $\begin{array}{l}\text { 6. Northern Birch Credit Union Limited } \\
\text { (Estonian) }\end{array}$ & \\
\hline $\begin{array}{l}\text { 7. St. Stanislaus-St. Casimir's Polish Parishes } \\
\text { Credit Union Limited (Polish) }\end{array}$ & \\
\hline 8. Talka Credit Union Limited (Lithuanian) & \\
\hline 9. Ukrainian Credit Union Limited & \\
\hline
\end{tabular}

Source: FSRA website. Data last reviewed on 27 July 2020.

According to the FSRA data, the Korean and Taiwanese organizations are the only racialized credit unions in Ontario. European immigrant communities (Ukrainian, Dutch, Finnish, Italian, Slovenian, Estonian, Lithuanian) make up the remainder of the organizations. After a number of reviews of these credit unions on Linkedln and Twitter feeds as well as websites, it is important to note that there is an absence of Black, South Asian, and Indigenous credit unions, and the leadership of the ones listed here are also missing BIPOC Canadians.

Some of Canada's largest credit unions, such as Meridian and Desjardins, have been able to conquer minority language exclusions, but they have been limited in their focus on BIPOC groups. Alterna Savings and Credit Union, one of Ontario's oldest credit unions, has a community investment portfolio (which used to be a microfinance program) that reaches mainly racialized people. But this unit is separate from its core business and has been sustained through the efforts of two Jamaican-Canadian women. Co-operatives in Canada seem to be preoccupied with whiteness, excluding BIPOC and other marginalized people. There has been, and continues to be, no consideration of the racism that is occurring within co-operative institutions-both within the practice and in the research of these institutions.

All three discourses thus reveal that BIPOC communities are missing from Canadian discussions on co-operatives. Of the three discourses, however, the Indigenous, with its acknowledgement of race and exclusion, is most relevant for BIPOC in Canada. In fact, the revered Neechi principles on how to build sustainable and locally owned community economic development are rooted, as mentioned above, in self-sufficiency. This theory of self-sufficiencyproducing what you can consume and taking an internal focus-is built on the early thinking of Afro-Guyanese economist C.Y. Thomas (1974). The idea of remaking community economic development in Canada for Indigenous people is rooted in ideas of the Black diaspora. Building on this connection, we need to add a fourth discourse to include the experiences of BIPOC Canadians in co-operatives. These experiences will speak not only to an alternative model for business but also to inequality and business exclusion in Canada. 


\section{Disrupt the dominant discourses on co-operative experience}

Ian MacPherson (1979; 2007; 2009; 2012), a leader in co-operative studies in Canada, recognized that the formation of co-operatives by racialized immigrants came in waves. Japanese Canadians were particularly resourceful in developing marketing co-operatives, but they were forced off their lands during the Second World War. Jo-Anne Lee et al. (2017), for example, listed a dozen Japanese-Canadian fishing co-operatives that were shut down by the government of Canada as part of the process of confiscating property and interning Japanese Canadians during the Second World War (p. 552). MacPherson (2007) finds that Koreans, Filipinos, and Sikhs from India have formed co-operatives in banking, medical services, and job creation (p. 134)-diaspora contributions that are largely unknown. A pattern emerges from the co-operative development that ethnic minorities establish for themselves as a pathway to access goods and services.

A number of scholars have explained that co-operatives in Canada have failed to open their membership to racialized groups - and open membership is an important principle for co-operatives. The housing co-operative sector presents particular challenges. Raphaël Fischler et al. (2017; 2013) describe the difficulties of social integration of immigrant households in co-operative housing, where new racialized immigrants come into conflict with existing housing co-operative residents in Montreal. Similarly, in her thesis, Gisele Yasmeen (1993) finds that there is a conflict between new racialized immigrants and existing co-operative members of a feminist housing co-operative in Montreal, citing "race relations" (p. 92) and surveillance by other co-op members as some of the disadvantages of co-operative housing. Cultural and linguistic differences also serve as barriers between Haitian and white French Canadians, in which mutual aid could be valuable.

Thomas $(1974 ; 1988)$ works to transform economies away from the binary of Marxism or capitalism in a way familiar to Black people, especially those who migrate from oppressive and racially class-tiered societies. Black people are intuitively aware of the need for self-sufficiency in their own locales, away from elites. This is why self-help and co-operative work are culturally relevant, very much like the Neechi principles. The many examples of the faltering and failure of Black co-operatives in Canada signals that there is no help for Black co-ops in the country. Existing co-ops are not culturally diversified to meet the needs of newcomers.

There are, however, stories of success. Lee and Curry (2015) have discovered a successful housing co-operative by a primarily Chinese community in Vancouver. Jorge Sousa (2015, p. 67) describes the successful transformation of a social housing complex into the Atkinson co-operative by immigrant residents in downtown Toronto, the first complex of its kind in Canada. The Atkinson case highlights the role of co-operation in community development, specifically how co-operative principles can work to uplift marginalized communities. Canada's first Black paper for women, Our Lives, was started by the Black Women's Collective (1986-1989) in Toronto, documenting racism and sexism in society (see Photo 2). Members paid monthly dues and the collective emphasized solidarity and education (Rise Up! 2020; Haritaworn et al., 2018; Stikeman \& Brand, 1991; Black Women's Collective Constitution, 1988). For the Black Women's Collective it was pragmatic for the members to use co-operative structures as a way to band together to fight against racism. 


\title{
Photo 2: The cover of an issue (1991) of Our Lives, Black Women's Collective in Toronto
}

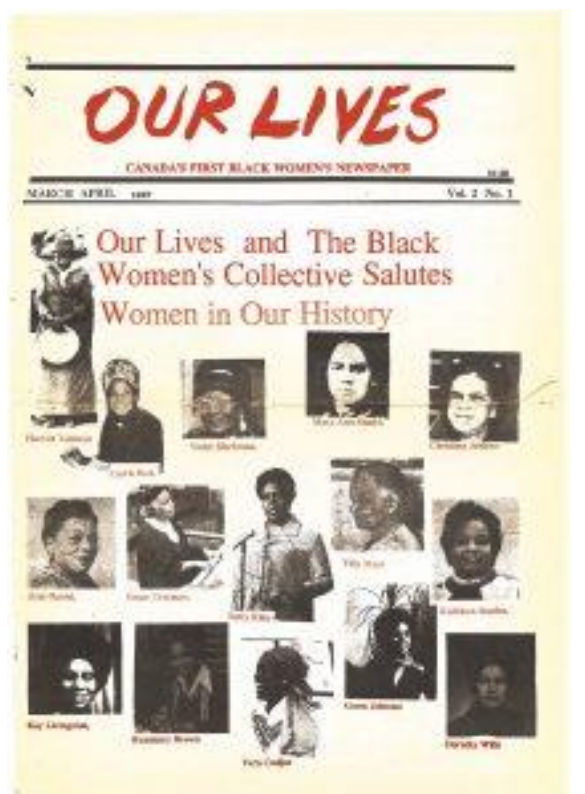

Source: Rise up! A Digital Archive of Feminist Activism

The 2020 Black protests revealed more than ever a need to culturally diversify the membership in Canadian co-operatives and related academic associations. The late lan MacPherson (2012), who played a leadership role in the global co-op sector, argued that we need to culturally diversify the sector:

\begin{abstract}
An important point was the recognition, in the Voluntary and Open Membership principle, that co-operatives should be open to people without "gender, social, racial, or religious discrimination". Given the different attitudes towards gender equality around the world at the time, this was not achieved without debate, particularly in some southern countries. Similarly, the idea that race should not count was not always easily accepted in places where it demonstrably and historically did. (p. 119)
\end{abstract}

Several works have examined the failed efforts of the Black diaspora in a number of domains in the country, and many of these limitations are due to the hostile racist environment (Nelson \& Nelson, 2004; Clairmont \& Magill, 1999; Winks, 1997; Du Bois, 1907). Examples of these cases include the Toronto United Negro Credit Union formed in the 1920s by members of Marcus Garvey's Universal Negro Improvement Association (Toney, 2010; Lewis, 1987); and the Commonwealth Co-operative Buying Club, the community collective credit initiative that the Toronto United Negro Association grew out of in the 1920s (Lewis, 1987). The Toronto United Negro Association, in turn, formed a Credit Union in the 1940s (Gooden, 2019). Another credit union was formed through Canada's first Black Union, the Order of Sleeping Car Porters, as early as 1937 in Winnipeg, Manitoba (Gordon Nembhard, 2014; Mathieu, 2001, 2002; Chateauvert, 1997). These associations were helpful during these difficult years of overt racism and discrimination.

More recently the Black diaspora has tried to create its own credit unions. A first effort was made by the Jamaican Canadian Association in 1963 in Toronto, but it had to fold because of management issues ("Jamaican Canadian Association," n.d.). The Seaview Credit Union was created in 1969 in response to racism in the historical Black Canadian town of Africville, Nova Scotia. However, this bank did not last because members did not repay loans, signalling that the credit union did not have the support needed to develop its capacity (Clairmont \& Magill, 1999, pp. 14-15). These results amplify the failure of the established co-operative system to assist other co-operatives, which is a core co-operative principle (see ICA, n.d.). In 1993, the Caribbean African Canadian Credit Union was 
launched in Toronto but failed due to various internal matters as well as a withdrawal of government funding after a change in the ruling party (Haliechuk, 1993; Hemeon, 1993).

Black Canadians want co-operatives led by people of colour, and they know the value of being co-operators; yet no government has assisted these co-ops with capitalization. The cases also raise the question of whether established credit unions have adhered to the ICA principles of aiding co-operative development. Meanwhile in the United States, Black co-operatives do exist despite a past that has been destroyed by "white competitors (who) used slander, violence, murder, physical destruction, and economic sabotage" (Gordon Nembhard, 2014, p. 29). There seems to be no shortage of documentation that speaks to the failed co-operative experiences among the diaspora. Negative media reports on cases that have failed do not put these experiences within the context of racial capitalism.

Credit unions that serve African Americans reach people alienated by the formal financial sector. For years economist Curtis Haynes' work (2019, p. 130) has documented Du Bois' thinking about "the condition of Black America", which called for Blacks to create their own economic means. A "racial isolation", Haynes (2019, p. 130) argues, "transcended all other social differences" and underpinned Du Bois' ideas of racial co-operation. Haynes (2019) finds that collective action by Black communities is a means by which to respond to harsh socio-economic conditions. The fact that there is no Black Canadian-led credit union or co-operative is telling.

The Toronto Star recently reported on the efforts of African Canadian organizations to develop a Pan African Credit Union (Miller, 2020) to provide financial access to Black entrepreneurs and Black-owned businesses, recognizing the systemic barriers faced by populations of colour. In July 2020, the Pan African Credit Union with the Jamaican Canadian Association and Lion's Club had a steering committee meeting via Zoom to discuss the market study and to understand the capitalization requirement.

\section{Politicized solidarity and the Black co-operator experience}

There are reportedly more than 200 million people of African heritage living in the Americas and the U.N. has dedicated a decade (2014-2023) to observe the contributions of the African diaspora, and yet its co-operative experience is virtually unknown in Canada. The Black social economy is an epistemology that is aimed as politicized work that co-opts business forms and makes them co-operative, often informally, as a way to reach those left out of mainstream society (Hossein, 2019; 2020). A review of the International Labour Organization's (ILO) website and its material reveals that there is limited material covering collective and informal co-operatives of racialized people in the West.

Political economy focused on racial minorities would benefit from drawing on theories that reflect the Black experience. Mutual aid was part of survival for enslaved and colonized Black people in the United States, Canada, and the Caribbean (e.g., Marcus Garvey's Universal Negro Improvement Association (UNIA) member-based movement). Black people in the diaspora are aware of this history and the continued ways group economics help them in dominant white/ened societies (Hossein, 2017b). Haynes (2019) has written a detailed article positing that W.E.B Du Bois' commitment to co-operatives was a way to counteract a racist society; as early as 1907, Du Bois, a Harvard-educated African American, advanced the theory of group economics among Black people to withstand white racist power. In 1901, Booker T. Washington (2013[1901]), imagining a world in which Black people did not have to fear lynching, devoted resources to anti-lynching campaigns. The Underground Railroad (1790-1860s) organized covertly and moved slaves from the United States into Canada, and this is often viewed as a co-operative movement that faced many challenges (Gordon Nembhard, 2014).

Black minorities, drawing on these ideas, have always used various forms of co-operation to cope in society (Haynes, 2019; Gordon Nembhard, 2014; Rothschild, 2009). Hossein (2013; 2017a) points out that ROSCAs, organizations primarily run by racialized people, are a form of co-operation that is often overlooked. The African diaspora in Canada, the United States, and Europe use these systems as a way to combat exclusion. In a recent MA thesis, Michael Tadesse (2020) documents the Ethiopian diaspora's use of Equub as a way to cope with racism in Berlin, Germany. Dutch academics Julie-Marthe Lehmann and Peers Smets (2019), through numerous interviews, have uncovered that Ghanaians and Nigerians in Amsterdam engage in ROSCAs as a form of group business and banking 
to help one another in an exclusionary environment. Black people in the West are thus actively engaged in co-operatives; but their form of informal co-operation is unacknowledged as a way to democratize banking.

\section{The Underground Railroad (1790s-1860s) and True Bands}

Mutual aid, self-help groups and ROSCAs are largely absent from academic literature. Stories that focus on racialized people in Canada are even harder to come by. Du Bois' (1907) research examined collective forms of African business, and this historical grounding inspires the Black diaspora outside of the African continent. The Underground Railroad is one example. Black Canadian scholar and owner of the Buxton Museum in southwestern Ontario, Bryan Prince (2004) explains that the Underground Railroad was a

secret network of good hearted people, black and white, who risked their safety and their lives to help fugitives find their way to Canada. Over thirty thousand people are estimated to have found safety and a new home in Canada prior to the American Civil War, and the constitutional amendment of 1865, which finally put an end to slavery in the United States. (p. 44)

The Underground Railroad was, without a doubt, a co-operative. It relied on the pooling of economic resources and good will to help enslaved Black people escape poverty. This form of co-operative had to be hidden because of the dangers of moving people into freedom, which could result in death. When the Africans settled into Canada, in towns like Buxton, Ontario, "true bands" were created to help people receive the goods they needed to live.

The historical context for the development of Black co-operatives in Canada must take into account these precursors of formal co-operatives developed by free Blacks that settled in Canada. Gordon Nembhard (2014, p. 34) describes self-sustaining communal Black farms and communes operating in Wilberforce, Ontario as early as 1831, a finding that predates the Desjardins and Antigonish movements. Lia Haro and Romand Coles (2019) argue that true bands by Black immigrants had to operate underground because they would be seen as breaking the law and could endanger the newly arrived Black refugees (p. 658). Benjamin Drew (1856) documented some of the earliest firsthand accounts of co-operatives and Black folks who escaped slavery to Canada. He defined true bands as co-operatives: "A True Band is composed of colored persons of both sexes, associated for their own improvement. Its objects are manifold: mainly these: the members are to take a general interest in each other's welfare; to pursue such plans and objects as may be for their mutual advantage" (p. 236).

Michael Hembree (1991) emphasized the importance of true bands for the integration of Black people who did not want to be dependent on handouts or charity in these communities. In 1853, a Black convention held at Amherstburg in Essex County in Ontario established vigilance committees in eight communities to coordinate relief for the refugees. The first true band society was funded by its own members in Maiden in 1854; and by 1856, Black people had organized 14 similar societies (Hembree, 1991, p. 321). Shirley Yee (1994) describes the critical role true bands played in the 1800s in the organizational networks that sustained Black communities who faced racism after they settled in Canada through the Underground Railroad. She finds:

Perhaps the best-known Black Canadian benevolent organizations were the "true bands." In 1856 Benjamin Drew counted fourteen of these organizations in Canada West. The goal of the bands was to foster independence by raising money to improve schools, providing temporary assistance to needy Black families, and caring for the sick. (p. 62)

\section{Counting ROSCAs, self-help groups and mutual aid collectives as co-operatives}

Harvard's Henry Louis Gates' (2018) Africa's Great Civilizations, a six-hour series on PBS, documents the co-operative effort to build kingdoms in Ethiopia and the Dahomey. The Ghana Susu co-operative system is highly revered and the state has regulated aspects of it (Aryeetey \& Steel, 1994). Fritz Bouman (1995) argues that it is impossible to know the origins of these ancient rotating savings systems.

It is hard to locate the beginnings of co-operatives among the African diaspora in Canada. As long as people migrated by way of the Underground Railroad and as immigrants, they brought their co-operative systems, including the true bands as far back as the 1800s. For example, the Hornsey Co-operative Credit Union in England was formally 
registered by West Indian immigrants in 1962 and later merged with the London Capital Credit Union in 2013 (Greaves, n.d.; O'Connell, 2009). African Americans started with mutual aid associations and built formal community focused credit unions (Rothschild,2009; Haynes \& Gordon Nembhard, 1999; Stewart, 1984).

The data about BIPOC co-operatives in Canada is missing or too old. The Canadian Worker Co-operative Federation (2009) and the Canadian Co-operative Association (2011) published reports more than a decade ago explaining why racialized Canadians do not form co-operatives. Some reasons included: a lack of awareness of what co-operatives are; lack of support from other organizations; limited financial means; lack of time; challenges with language, culture, and academic education; differing cultural definitions of what it means to be a co-operative. These reasons (read: excuses) deny that there is inaction by established co-operatives to assist informal co-operatives. Black Canadians know about co-operative systems, but due to the racist environment have had to organize below the radar for fear of being harassed.

One form of informal co-operative institution is ROSCAs, which are purposefully informal. ROSCAs are not underdeveloped co-operatives. Members voluntarily organize and join in these groups rooted in values of democracy, equity and voice. Racialized Canadians in my decade-long empirical work tell me that they understand the co-operative model, and studies which repeat the narrative that they do not are problematic. What is missing is the technical and financial support to ensure culturally diverse co-operatives. A study by the University of Toronto (Maiorano et al., 2017) revealed that credit unions in the Greater Toronto Area (GTA) were not located in racially marginalized communities, and it was more likely for the few offices they had to be in affluent parts of the City of Toronto. Meridian Credit Union, for example, has offices at Yonge \& Sheppard, The Danforth, and The Beaches. A review of LinkedIn profiles by research assistants suggest that senior management in the prominent credit unions lacked cultural diversity in the leadership teams and on the boards.

\section{Hiding in plain sight: ROSCAs and mutual aid by immigrants}

Black Canadians have been hiding in plain sight in terms of co-operatives because being informal does not count in the co-operative sector. Black Canadian scholars (Walcott et al., 2019; James et al., 2010; Mensah, 2010) have all noted that the negative impact of the legacy of slavery in Canada persists in the systems we have today and affects Black life in education, housing, business and the law. It is due to systemic racism that Black people, especially women, have created informal financial co-operatives. The hundreds of Black Canadian women I have interviewed over the years have had to approach their informal co-operative systems with discretion because of the unsafe living environment and bias they encounter every day.

Photo 3: Photo of one scene in the film, The Banker Ladies.

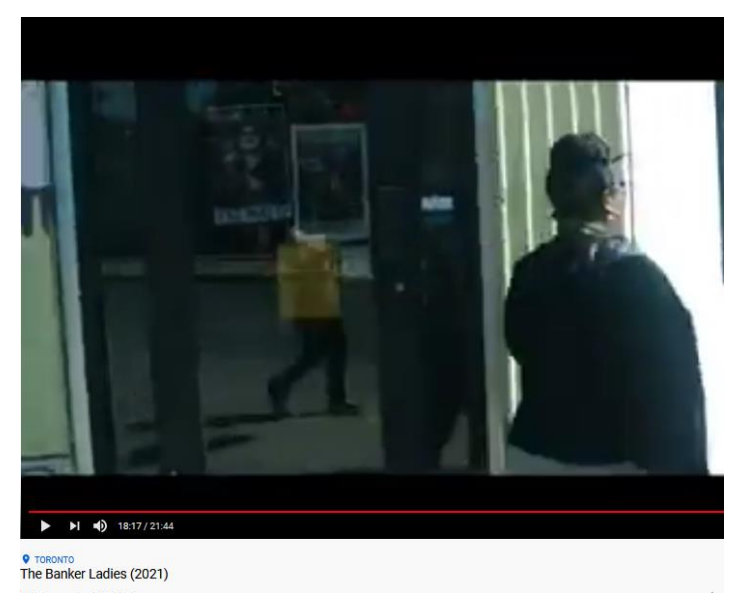

Photo by author.

Black Canadian women hide their ROSCAs because they worry that the informality of these systems would be viewed harshly. Being routinely discriminated against and treated as inferior makes marginalized people opt for secrecy and 


\section{Caroline Shenaz Hossein}

keeping a low profile on what they do (Hossein, 2020; 2018a; Gordon Nembhard, 2014). The Banker Ladies documentary film (dir Mondesir, 2020) shows how Black women from the Caribbean and Africa participate in various forms of banking co-operatives to counteract business and social exclusion. For centuries, African and Caribbean women around the world have mobilized scarce resources in low-income communities (Hossein, 2017a, 2018a, 2018b; Ardener \& Burman, 1996). Sidney Mintz (2010) documented the use of a sistem pratik that relied on collectives, such as Sol, by the local sellers (Madam Saras) to create a vibrant marketplace. Gordon Nembhard (2014) found that African American women in Alabama created the Freedom Quilting Bee Co-operative to feed, shelter, and help their families and communities meet their needs, as well as to mitigate the harms of white supremacy. Feminist economists Deborah Figart (2014) and Ngina Chiteji (2002) have also shown how informal banks in the United States structured as co-operatives prove to be cost effective forms of financing for racialized Americans.

The ROSCAs that are informally organized among the GTA's Black diaspora are diverse, with women representing 15 countries in Africa and the Caribbean. Many other newcomers to Canada-from Pakistan, China, Korea, Mexico, Sri Lanka, Ecuador, and India to name a few-also run and participate in ROSCA systems. "Natla," a 35-year-old married Sudanese Canadian woman I interviewed in Toronto in 2015 , saw this system as the only one to help her settle into Canada:

Who knows me here when I first come from Sudan [pause]. No one. I can't even speak English back then. Sandooq [an informal co-operative bank] give me friends and a chance. I buy [bought] my airplane ticket back home and bring my children for there [for vacation]. Sandooq helped me so much when I came to Canada. I swear to my God for it.

Documented experiences of racism in the behaviour of mainstream banks can explain why racialized people choose to participate in alternative banking services. In December 2014, Haitian Canadian Frantz St. Fleur was arrested on the suspicion that he was trying to deposit a fraudulent check from Remax at his Scotiabank branch in Toronto's east end, where he had been a customer for ten years (Hossein, 2018b; Alamenciak, 2014); it turned out the check was credible. In January 2020, Maxwell Johnson and his 12-year-old grand-daughter were handcuffed by police after the Bank of Montreal (BMO) wrongfully suspected them of illicit behaviour (Sterritt, 2020); in this case, as well, it turned out the suspicions were groundless. And in February 2020, Egyptian Canadian Dana Ramadan went into the Royal Bank of Canada in the west end of the GTA where tellers allegedly accused her of illegal activities for wanting to withdraw her own money (Paradkar, 2020).

Given these experiences, it seems logical that people would turn to informal institutions for help. In Hard Choices, Jerry Buckland (2012) examines a number of reasons why excluded people go to alternative providers like Payday lenders, but he does not consider ROSCAs as an alternative. In fact, no one is thinking about ROSCAs as co-operatives that help people. ACORN Canada has reported that only 3 percent of the population (i.e., 842,000 Canadians) are unbanked, meaning they have no access to financial services (ACORN, 2016). Less is known about Canadians who are "underbanked". Why do critics examine ROSCAs as a way to address banking exclusion? This term "underbanked" refers to people who have bank accounts but only engage with accounts minimally to make deposits. ROSCAs are seemingly helping excluded Black Canadian women access lump sums of monies to meet livelihood needs.

Black Canadian women I interviewed like "Fardowsa," a Somali-born Canadian and resident of Jane and Finch in Toronto explained the cultural aspect of ROSCAs:

We are bringing change through our own banking ways. Hagbad. It helps me to keep doing what I do when they (critics who do not know about informal co-operatives) look at us in a weird way to say it's our culture. We show we can do it [business] ourselves and also ... is a social thing ... We drink tea and talk.

This statement reveals that beyond exclusionary issues, Black Muslim women like "Fardowsa" opt to join ROSCAs called Hagbad because of the informality of these cultural co-operatives. The Somali Hagbad meetings are reminiscent of the kitchen meetings of the male fisher folks in the Antigonish movement who wanted to try a cooperative system so that they had a voice. Somali Canadians gather in the safe space of someone's home or the 
room of a local community centre to discuss their lives and the politics of the day while enjoying a potluck of tea, fish samosas and rice before getting to the group business.

\section{Conclusion: Going beyond Rochdale to understand the Black Canadian co-operator experience}

The African diaspora have been leading co-operatives for a very long time. African people in bondage and fighting for social justice held onto collective money systems they knew well and had to do so in secret (St. Pierre, 1999; Stewart, 1984). The timelines of group co-operation for African people began well before the Rochdale weavers of England.

Knowing the legacy of hidden co-operatives within informal spaces, is important to the Canadian co-op sector. This also means that there is a real need to widen the definition of co-operative to ensure that ROSCAs and other mutual aid groups of BIPOC Canadians are included. Black people have always known about co-operation due to a treacherous lived experience of racial capitalism (Robinson 1983). They have had to purposely hide what they do , and they collectively agitate to meet their goals (Hossein, 2019; Gordon Nembhard, 2014). The Afro-Guyanese economist C.Y. Thomas was instrumental in forming the Neechi principles, which guide co-operative economic development in Canada today; yet there is a convenient imagination that newcomers do not know about cooperatives. The erasure of Black people in the literature and in actual membership of formal co-operatives is happening. In 2020, the global body on co-operativism, the International Co-operative Alliance, has no formal representation of the African diaspora, and the closest representative is the portfolio of Africa.

On $21^{\text {st }}$ October 2020 at the fourth annual Co-op Impact conference of the National Cooperative Business Association, Professor Jessica Gordon Nembhard's lecture made it pointedly clear that co-ops can be racist in spite of the principle of "open membership." Ignoring the Black experience because the Black co-operators sought refuge is part of the co-operative story for the Western world. The Underground Railroad is a towering example of economic co-operation that had to be informal because it was risky as Black people were escaping slavery.

Valuing the informal co-operative experience is how Canadian co-operatives will attract Black Canadians and especially Black women to the movement. Informal co-operativism needs to feature prominently in the co-operative narratives in Canada. Knowledge of the work of true bands is carried through oral history and includes many details to locate how these co-operatives helped slaves to settle into Canada. ROSCAs, mutual aid and self-help groups all comprised of deliberately informal co-operatives are used by BIPOC Canadians across the country. These variations should be considered in the context of where the African diaspora live and why cooperating is done this way. The Black Banker Ladies who organize ROSCAs operate their ROSCAs out of the public view because they are stigmatized and their funds have been confiscated because informal co-operatives are not recognized as mutual aid and selfhelp. Future research should be moving the state along the path of subsidizing mutual aid and informal co-operative development as a way to address inequities.

By ignoring the value of informal co-ops of the African diaspora, the co-operative movement misses out on the benefits of Black and mostly women-led co-operatives. Now that the sector understands that erasure of the Black co-operator experience has happened, there is a need to repair this harm from within the sector. At every turn I am making the case that there is a need for a national ROSCA network to be led by BIPOC women (not men) and this is vital. Black women, particularly those from low and middle income backgrounds, are proving to be the very epitome of trustworthiness and co-operation. The women should be viewed as the experts on how equitable banking functions in an anti-Black racist society. This may be the opening that is needed for a declining co-operative sector to boost its membership and to culturally diversify. But the co-op sector will first have to look at how to make their own institutions representative of cultural diversity at every level, and then evolve to recognize scholarship and practice by BIPOC Canadians in co-operative development.

\section{References}

ACORN Canada. (2016). It's Expensive to Be Poor: How Canadian Banks Are Failing Low Income Communities. Acorn Canada [website]. 
Alamenciak, Tim. (2014). "Banking while Black." Toronto Star, 10 December. https://www.thestar.com/news/gta/2014/12/10/banking while black toronto man accuses scotiabank of racial_profiling.html

Anderson, Robert Brent. (1999). Economic Development among the Aboriginal Peoples of Canada: The Hope for the Future. Concord, Ontario: Captus Press.

Ardener, Shirley, \&Burman, Sandra. (1996). Money-Go-Rounds: The Importance of Rotating Savings and Credit Associations for Women. Oxford, UK: Berg.

Aryeetey, Ernest \& Steel,William. (1994). “Informal Savings Collectors in Ghana: Can They Intermediate?” Finance and Development, 31(1), 36-37.

Atleo, Clifford G. (2015). “Aboriginal Capitalism: Is Resistance Futile or Fertile?" Journal of Aboriginal Economic Development, 9 (2), 41-51.

BBC Horizon. (1980). The Mondragon Experience. TV series.

Bekerie, Akele. (2003). "Iquib and Idir: Socio-Economic Traditions of the Ethiopians." Tadias Online. http://www.tadias.com/v1n6/OP_2_2003-1.html

Bekerie, Akele. (2008). "The Ethiopian Millennium and Its Historical and Cultural Meanings." International Journal of Ethiopian Studies, 3(2), 23-31.

Belhadji, El Bachir Abdelouahid. (2001). Socio-Economic Profile of Aboriginal Co-operatives in Canada. Co-operatives Secretariat, Government of Canada.

Black Women's Collective Constitution. (1988). Rise Up: A Digital Archive of Feminist Activism. https://riseupfeministarchive.ca/activism/organizations/black-womens-collective/blackwomenscollective1988-constitution-2/

Bouman, Fritz J. A. (1995). "ROSCA: On the Origin of the Species." Savings and Development, 19 (2), 117-48

Brathwaite. Kamau. (1981). The Arrivants: A New World Trilogy (Rights of Passage; Islands; Masks). Oxford, UK: Oxford University Press.

Brothers, S., Mistruzzi, L., Smolski, A., \& Preston, M. (Dirs.). (2017). A Silent Transformation: A film about the transformative power of the cooperative enterprise model. Powerline films (Bullfrog in US). 70 minutes.

Buckland, Jerry. (2012). Hard Choices: Financial Exclusion, Fringe Banks, and Poverty in Urban Canada. Toronto, ON: University of Toronto Press.

Canadian Co-operative Association (CCA). (2011). Ethnocultural and Immigrant Co-operatives in Canada. Cooperatives and Mutuals Canada. https://canada.coop/

Chateauvert, Melinda. (1997). Marching Together: Women of the Brotherhood of Sleeping Car Porters. Champaign, IL: University of Illinois Press.

Chiteji, Ngina, S. (2002). "Promises Kept: Enforcement and the Role of Rotating Savings and Credit Associations in an Economy." Journal of International Development, 14(1), 393-411.

Christabell, P. J. (2013). "Social Innovation for Women Empowerment: Kudumbashree in Kerala." Innovation and Development, 3(1), 139-40.

Clairmont, Donald H. J. \& Magill, Dennis W. (1999). Africville: The Life and Death of A Canadian Black Community. Toronto, ON: Canadian Scholars' Press.

Corcoran, Hazel. (2009). Strategies for Developing Immigrant Worker Co-ops. Canadian Worker Co-operative Federation. https://canadianworker.coop/strategies-for-developing-immigrant-worker-co-ops/.

Cox, Oliver Cromwell. (1959). The Foundations of Capitalism. New York: Philosophical Library Inc.

Cox, Oliver Cromwell. (1964). Capitalism as a System. New York: Monthly Review Press.

Curl, John. (2012). For All the People: Uncovering the Hidden History of Cooperation, Cooperative Movements, and Communalism in America. Oakland, CA: PM Press.

Dana, Leo Paul. (2010). "Nunavik, Arctic Quebec: Where Cooperatives Supplement Entrepreneurship." Global Business and Economics Reviewl, 12 (1-2), 42-71.

Datta, Rekha. (2000). "On their Own: Development Strategies of the Self-Employment Women's Association (SEWA) in India." Developmentl, 43(4), 51-55.

Davies, Thomas. (2018). "Historical Development of NGOS." In The Handbook on Research on NGOs, Aynsley Kellow \& Hannah Murphy-Gregory (Eds.), (pp. 15-34). Cheltenham, UK: Edwards Elgar Publishing. 
Drew, Benjamin. (1856). A North-Side View of Slavery: The Refugee: or, The Narratives of Fugitive Slaves in Canada. Related by Themselves, with an Account of the History and Condition of the Colored Population of Upper Canada. Boston, MA: J.P. Jewett.

Du Bois, W.E.B. (1907). Economic Co-operation among Negro Americans. Atlanta, GA: Atlanta University Press.

Dworkin, Mark \& Young, Melissa, (Prods). (2012). Shift Change: Putting Democracy to Work. 2012. [Film] Bullfrog. U.S.

Fairbairn, Brett. (1994). The Meaning of Rochdale: The Rochdale Pioneers and the Co-operative Principles. Occasional Paper. Saskatoon, SK: Centre for the Study of Co-operatives, University of Saskatchewan.

Fairbairn, Brett. (2004). "History of Cooperatives." In Cooperatives and Local Development: Theory and Applications for the 21st century. In Christopher D. Merrett \& Norman Walzer (Eds.), (pp. 23-51). Armonk, New York: M.E. Sharpe.

Fairbairn, Brett. (2005). “Canada's Co-operative Province: Individualism and Mutualism in a Settler Society 19052005." Reflections in Celebration of Saskatchewan's Centennial Year. Saskatoon, SK: University of Saskatchewan, Centre for the Study of Co-operatives. E-book.

Fairbairn, Brett. (2007). "A Century of Prairie and Saskatchewan Farm Cooperatives: Philosophy, Organization and History." The Prairie Agrarian Movement Revisited, 93-106. Regina, SK: University of Regina, Canadian Plains Research Center.

Fairbairn, Brett. (2009). "Canada's Co-operative Province: Individualism and Mutualism in a Settler Society". In Perspectives of Saskatchewan, Jene M. Porter (Ed.), (pp. 149-74). Winnipeg, MB: University of Manitoba Press.

Figart, Deborah M. (2014). “Underbanked and Overcharged: Creating Alternatives to "Alternative Financial Service Providers." Dollars \& Sense, 9-11. (no volume)

Financial Services Regulatory Authority of Ontario (FSRA). "Ontario Credit Unions and Caisses Populaires." http://creditunion.fsco.gov.on.ca/english/

Findlay, Isobel M. (2006). "Putting Cooperative Principles into Practice. Lessons Learned from Canada's North." Review of International Cooperation, 99 (1). 44-52.

Findlay, Isobel M., \& Wuttunee, Wanda. (2007). Aboriginal Women's Community Economic Development: Measuring and Promoting Success. IRPP Choices 13(4), n.p.

Fischler, R., Kraemer, S.\& Wiginton, L. (2017). “A Place to Stand Up on Your Two Feet: The Community Housing in Immigrant Integration in Montréal, Quebec", Revue canadienne de recherche urbaine, vol. XXVI, 2, 15-32.

Fischler, R., Aubin, R., Kraemer, S., \& Wiginton, L. (2013). "Cooperative Housing and the Social Integration of Immigrant Households." Quebec Metropolis Centre - Immigration and Metropolis, Working Paper No. 52. http://www.metropolis.inrs.ca/working-paper-no-52-cooperative-housing-and-the-social-integrationof-immigrant-households/.

Galabuzi, Grace-Edward. (2006). Canada's Economic Apartheid: The Social Exclusion of Racialized Groups in the New Century. Toronto, ON: Canadian Scholars Press Inc.

Gates, Henry Louis. (2018). Africa's Great Civilizations. [Six hour series.] PBS, 25 May.

Gibson, R., Kobluk, D., \& Gould, L. (2005). "The Co-operative Movement: A Historical Overview and Relevance to Northern and Aboriginal Communities." RDI Working Paper 2005-1. Rural Development Institute (RDI), Brandon University.

Gibson-Graham, J. K. (1996). The end of capitalism (as we knew it): A feminist critique of political economy. Oxford, UK: Blackwell Publishers.

Gibson-Graham, J. K. (2003). 'Enabling ethical economies: Cooperativism and class,' Critical Sociology, 29(2), 123161.

Gibson-Graham, J. K. (2006). A postcapitalist politics. Minneapolis: University of Minnestota Press.

Gooden, Amoaba. (2019). Chapter 4 "African Canadian Leadership: Pan-Africanism, Transnationality, Community Organizing." African Canadian Leadership: Continuity, Transition, and Transformation. In Tamari. Kitossa, Erica S. Lawson, and Philip S. S. Howard (Eds.), (pp. 111-48). Toronto, ON: University of Toronto Press.

Gordon Nembhard, Jessica. (2008). "Cooperatives." International Encyclopedia of the Social Sciences. 2nd ed. William A. Darity (Ed.), (pp. 123-27). Farmington Hills, MI: Macmillan Reference USA.

Gordon Nembhard, Jessica. (2014). Collective Courage: A History of African American Cooperative Economic Thought and Practice. University Park: Pennsylvania University Press. 
Gordon Nembhard, Jessica. (2020). Racial Equity in Co-ops: 6 Key Challenges and How to Meet Them. Nonprofit Quarterly.

Grant, K., Love, K., \& Corcoran, H. (2018). "Farewell to Neechi Commons." Canadian Worker Co-operative Federation [website], 18 July. https://canadianworker.coop/farewell-to-neechi-commons/

Greaves, Elaine. (n.d.). "Board of Director" [bio] Credit Union [website]. https://www.creditunion.coop/content.asp?section $=258$

Guinnane, Timothy. (2001). "Cooperatives as Information Machines: German Rural Credit Cooperatives, 18831914." Journal of Economic History, 61(2), 366-89.

Haliechuk, Rick. (1993). “Credit Union Aims to Meet Black Needs." Toronto Star, 5 June, Section B.

Hammond Ketilson, Lou. (2006). Revisiting the Role of Co-operative Values and Principles: Do They Act to Include or Exclude? Centre for the Study of Co-operatives, University of Saskatchewan.

Hammond Ketilson, Lou. (2014). "Partnering to Finance Enterprise Development in the Aboriginal Social Economy." Canadian Public Policy 40. Supplement 1, S39-S49.

Hammond Ketilson, Lou, and lan MacPherson. (2001). A Report on Aboriginal Co-operatives in Canada: Current Situation and Potential for Growth. Centre for the Study of Co-operatives, University of Saskatchewan.

Haritaworn, J., Moussa, G., \& Ware, S. M. (2018). Queering Urban Justice: Queer of Color Formations in Toronto. Toronto, ON: University of Toronto Press.

Haro, Lia, \& Coles, Romand. (2019). "Reimagining Fugitive Democracy and Transformative Sanctuary with Black Frontline Communities in the Underground Railroad." Political Theory, 47 (5), 646-73.

Harriet Tubman Historical Society website: http://www.harriet-tubman.org/ Accessed 3 August 2020.

Harris, Judith, \& McLeod Rogers, Jacqueline. (2014). Partnering to Build a Social Co-operative for Aboriginal Women Transitioning from Prison. Journal of Co-operative Studies, 47(1), 25-38.

Hatcher, Renee. (2018). "Cooperation Chicago: Building Chicago's Worker Cooperative Ecosystem." Chicago, IL: Illinois Worker Cooperative Alliance and John Marshall Law School Business Enterprise Law Clinic. Retrieved from Grassroots Economic Organizing website, http://geo.coop/story/cooperation-chicago.

Haynes, Curtis. (2019). “From Philanthropic Black Capitalism to Socialism: Cooperativism in Du Bois's Economic Thought." Socialism and Democracy, 32 (3),125-45.

Haynes, Curtis. (2010). Commentary on Black Political Economy. The Journal of Philosophical Economics; Bucharest, $3(2), 164-72$.

Haynes, Curtis, Jr., \& Gordon Nembhard, J. (1999). Cooperative Economics-A Community Revitalization Strategy. The Review of Black Political Economy, 27 (1), 47-71.

Hembree, Michael F. (1991). "The Question of Begging: Fugitive Slave Relief in Canada, 1830-1865." Civil War History, 37 (4). 314-27.

Hemeon, Jade. (1993). “Black Credit Union Gets $\$ 750,000$." Toronto Star. 21 July. Section B.

Hossein, Caroline Shenaz. (2013). "The Black Social Economy: Perseverance of Banker Ladies in the Slums." Annals of Public and Cooperative Economics, 84 (4), 423-42.

Hossein, Caroline Shenaz. (2017a). "Fringe Banking in Canada: A Preliminary Study of the 'Banker Ladies' and Economic Collectives in Toronto's Inner Suburbs." Canadian Journal of Non-profit and Social Economy Research, 8 (1), 29-43.

Hossein, Caroline Shenaz. (2017b). "A Case Study of the Influence of Garveyism on the African Diaspora." Social Economic Studies Journal, 66 (3/4), 151174.

Hossein, Caroline Shenaz, (Ed.). (2018a). The Black Social Economy in the Americas: Exploring Diverse CommunityBased Markets. New York: Palgrave Macmillan.

Hossein, Caroline Shenaz. (2018b). "Banking While Black: The Business of Exclusion.” Conversation.com, May 7. https://theconversation.com/banking-while-black-the-business-of-exclusion-94892.

Hossein, Caroline Shenaz. (2019). "A Black Epistemology for the Social and Solidarity Economy: The Black Social Economy." The Review of Black Political Economy, 46 (3), 209-29.

Hossein, Caroline Shenaz. (2020). "Rotating Savings and Credit Associations (ROSCAs): Mutual Aid Financing." In Section 5 in The Handbook of Diverse Economies. J.K. Gibson-Graham and Kelly Dombroski (Eds.), (pp. 35461). Cheltenham, UK: Edward Elgar Press.

Iglauer, Edith. (2000). Inuit Journey: The Co-operative Adventure in Canada's North. Madeira Park, BC: Harbour Pub. 
International Co-operative Alliance (ICA). (n.d.). "Cooperative Identity, Values and Principles." https://www.ica.coop/en/cooperatives/cooperative-identity

"Jamaican Canadian Association." (n.d.). Jean Augustine Political Button Collection. York University Library. http://archives.library.yorku.ca/exhibits/show/pushingbuttons/black--caribbean-community/jamaicancanadian-association.

James, C., Este, D., Thomas Bernard, W., Benjamin, A., Lloyd, B., \& Turner, T. (2010). Race and Well-being: The Lives, Hopes and Activism of African Canadians. Halifax, Canada: Fernwood Publishing.

Johnston, A.J.B. (2001). "Research Note: Mathieu Da Costa along the Coasts of Nova Scotia: Some Possibilities," Journal of the Royal Nova Scotia Historic Society, 4, 152-64.

Kedir, Abbi M. \& Ibrahim, Gamal. (2011). "ROSCAs in Urban Ethiopia: Are the Characteristics of the Institutions More Important Than Those of Members?" Journal of Development Studies, 47 (7), 998-1016.

Lee, J., Smallshaw, B., \& Peredo, A.M. (2017). "Rethinking Co-operatives: Japanese-Canadian Fishing Co-operatives." Community Development Journal, 52 (4), 540-57.

Lee, Jo-Anne \& Curry, Nora. (2015). "Research Summary: Strathcona Co-op Housing." Project: Co-operatives in Context: Race, Ethnicity, Displacement and Exclusion. http://ec.msvu.ca:8080/xmlui/handle/10587/1512

Lehmann, Julie-Marthe, \&Smets, Peer. (2019). "An Innovative Resilience Approach: Financial Self-Help Groups in Contemporary Financial Landscapes in the Netherlands." Economy and Space, 1-18.

Lethabo King, Tiffany. (2019). The Black Shoals: Offshore Formations of Black and Native Studies. Durham, NC: Duke University Press.

Levesque, B., Malo, M-C., \& Rouzier, R. (1997). “The 'Caisse de dépôt et placement du Québec' and the 'Mouvement des Caisses populaires et d'Économie Desjardins': Two Financial Institutions, the Same Convergence towards the General Interest?" Annals of Public and Cooperative Economics, 68 (3), 485-501.

Lewis, Rupert. (1987). Marcus Garvey: Anti-Colonial Champion. Kent, UK: Karia Press.

Li, Wei \& Lo, Lucia. (2008). "People-Money Co-movement and the Ethnic Financial Sectors in Canada and the U.S." Migracijske i etnicke teme, 24 (4), 301-22.

Lionais, Doug, \& Hardy, Kim. (2015). Cooperatives and the Social Economy of the Yukon. In Northern Communities Working Together: The Social Economy of Canada's North, C. Southcott (Ed.). Toronto, ON: University of Toronto Press.

Loxley, John. (1985). "Regulation and Restructuring: Responses to the International Financial Crisis." Contemporary Crises; Dordrecht, Etc., 9 (2), 103-25.

Loxley, John. (2002). "Sustainable Urban Economic Development: An Aboriginal Perspective." Journal of Aboriginal Economic Development, 3 (1), 29-32.

Loxley, John. (2008). Doing Community Economic Development. Toronto, ON: Fernwood Publishing.

MacAulay, Scott. (2002). "The Smokestack Leaned toward Capitalism: An Examination of the Middle Way Program of the Antigonish Movement." Journal of Canadian studies, 37 (1), 43-67.

MacPherson, Ian. (1979). Each for All: A History of the Co-operative Movement in English Canada, 1900-1945. Vol. 116. Toronto, ON: McGill-Queen's Press-MQUP.

MacPherson, Ian. (2007). One Path to Co-operative Studies: A Selection of Papers and Presentations. British Columbia Institute for Co-operative Studies. Victoria, BC: New Rochdale Press.

MacPherson, Ian. (2009). "What Has Been Learned Should Be Studied and Passed On: Why the Northern Co-operative Experience Needs to Be Considered More Seriously." Northern Review, 30, 57-81.

MacPherson, Ian. (2012). “'...What Is the End Purpose of It All?': The Centrality of Values for Cooperative Success in the Marketplace." In The Cooperative Business Movement, 1950 to the Present, ed. Patrizia Battilani and Harm G. Schröter (Eds.), (pp. 107-25). Cambridge, England: Cambridge University Press.

Maiorano, J., Mook, L., \& Quarter, J. (2017). "Is There a Credit Union Difference? Comparing Canadian Credit Union and Bank Branch Locations." Canadian Journal of Nonprofit and Social Economy Research, 7 (2), 40-56.

Mathieu, Saje. (2001). "North of the Colour Line: Sleeping Car Porters and the Battle Against Jim Crow on Canadian Rails, 1880-1920." Labour / Le Travail, 47 (1), 9-41.

Mathieu, Saje. (2002). Jim Crow Rides This Train: The Social and Political Impact of African American Sleeping Car Porters in Canada, 1880-1939. PhD Thesis, Yale University. 
Mendell, Marguerite. (2009a). "The Social Economy of Quebec: Lessons and Challenges." In Co-operatives in a Global Economy: The Challenges of Co-operation across Borders, D. Reed and J.J. McMurtry (Eds.), (pp. 226-42). Newcastle-upon-Tyne, UK: Cambridge Scholars Publishing.

Mendell, Marguerite. (2009b). "The Three Pillars of the Social Economy in Quebec." In The Social Economy: Alternative Ways of Thinking About Capitalism and Welfare, Ash Amin (Ed.), (pp. 176-209). London: Zed Books.

Mensah, Joseph. (2010). Black Canadians: History, Experience, Social Conditions. 2nd ed. Halifax, Canada: Fernwood Publishing.

Miller, Ethan. (2010). "Solidarity Economy: Key Concepts and Issues." In Solidarity Economy I: Building Alternatives for People and Planet, edited by Kawano, E. and Masterson, T. and Teller-Ellsberg, J. Amherst, MA: Center for Popular Economics.

Miller, Jason. (2020). "Black Groups Seek to Launch Credit Union". Toronto Star, 20 February, GTA section.

Mintz, Sidney. (2010). Three Ancient Colonies: Caribbean Themes and Variations. Cambridge, MA: Harvard University Press.

Mirchandani, Kiran. (2002). "A Special Kind of Exclusion: Race, Gender and Self-Employment." Atlantis, 27, 25-38.

Mitchell, Marybelle. (1996). From Talking Chiefs to a Native Corporate Elite: The Birth of Class and Nationalism among Canadian Inuit. Vol. 12. Toronto, ON: McGill-Queen's Press-MQUP.

Mondesir, Esery. (Dir.). The Banker Ladies. 2021 (soft release in 2020). [Film]. Prod. DiSE Collective. https://www.filmsforaction.org/watch/the-banker-ladies/

Murphy, Peter. (Prod.). (2009). You Can Do It: The Story of the Antigonish Movement. [Film] Sea Bright Productions. National Council of Welfare Reports. (n.d.). Poverty Profile: Special Edition. Government of Canada.

"Neechi Principles." (n.d.). The Canadian CED Network [website]. https://ccednet-rcdec.ca/en/toolbox/neechiprinciples

Nelson, Charmaine, \& Nelson, Camille A. (Eds.). (2004). Racism, Eh? A Critical Inter-Disciplinary Anthology of Race and Racism in Canada. Vaughan, Ontario: Captus Press.

Nelson, Nici. (1996). “The Kiambu Group: A Successful Women's ROSCA in Mathare Valley, Nairobi (1971 to 1990). In Money-Go-Rounds: The Importance of Rotating Savings and Credit Associations for Women, ed. S. Ardener and B. Sandra (Eds.). (pp. 49-71). Oxford, UK: Berg.

O'Connell, Sean. (2009). Credit and Community: Working-Class Debt in the UK Since 1880. Oxford University Press on Demand.

Ontario Co-operative Association (OCA), website, accessed 3 August 2020. https://ontario.coop/

Palmer, Tim. (2019). Worker Cooperative State of the Sector Report, Democracy at Work Institute and the US Federation of Worker Cooperatives, E-book

Paradkar, Shree. (2020). "This Egyptian-Canadian Woman Went to Withdraw Her Own Money at RBC. What Happened Next is the Subject of a Lawsuit against the Bank and Peel Police." Toronto Star, February 6. https://www.thestar.com/news/gta/2020/02/06/this-egyptian-canadian-woman-went-to-withdraw-herown-money-at-rbc-what-happened-next-is-the-subject-of-a-lawsuit-against-the-bank-and-peelpolice.html.

Pattison, Dwayne. (2010). Self-Determination in Action: The Entrepreneurship of the Northern Saskatchewan Trappers Association Co-operative. Centre for the Study of Co-operatives.

Peterson, Iver. (1990). "As Co-ops Spread, Discrimination Concerns Grow." New York Times, February 25. https://www.nytimes.com/1990/02/25/realestate/as-co-ops-spread-discrimination-concerns-grow.html.

Prince, Bryan. (2004). I Came as a Stranger: The Underground Railroad. New York: Tundra Books.

Quarter, J., Mook, L., \& Armstrong, A. (2017). Understanding the Social Economy: A Canadian Perspective. Toronto, ON: University of Toronto Press.

Quiring, David. (2006). "From the Bush to the Village in Northern Saskatchewan: Contrasting CCF Community Development Projects." Journal of the Canadian Historical Association/Revue de la Société historique du Canada, 17 (1), 151-78.

Rebel Sky Media. (2018). The Inclusive Economy: Stories of CED in Manitoba. [Documentary] Winnipeg. Producers, the Canadian Community Economic Development Network, the Canadian Centre for Policy Alternatives. https://ccednet-rcdec.ca/en/new-in-ced/2018/01/12/inclusive-economy-stories-ced-manitoba 
Rhodes, Rita. (2012). Empire and Co-operation: How the British Empire used Cooperatives in its development strategies, 1900-1970. Edinburgh, Scotland: John Donald.

Rise Up! A Digital Archive of Feminist Activism. Accessed Our Lives information on 29 June 2020 https://riseupfeministarchive.ca/activism/organizations/black-womens-collective/?highlight=our\%20lives

Rothschild, Joyce. (2009). "Workers' Cooperatives and Social Enterprise: A Forgotten Route to Social Equity and Democracy." American Behavoralist, 52 (7), 1023-41.

Sengupta, Ushnish. (2015). "Indigenous Cooperatives in Canada: The Complex Relationship between Cooperatives, Community Economic Development, Colonization, and Culture." Journal of Entrepreneurial and Organizational Diversity, 4 (1), 121-52.

Sethi, Raj Mohini. (1996). "Women's Informal Cooperative Banks in Contemporary Indian Society." In Money-GoRounds: The Importance of Rotating Savings and Credit Associations for Women, S. Ardener and B. Sandra (Eds.), (pp. 163-79). Oxford, UK: Berg.

Smets, Peers. (1998). "Money-Go-Rounds for Women: Finance as Instrument or as Ultimate Goal in Lottery ROSCAs." Anthropos, 9, 209-15.

Sousa, Jorge. (2015). "Realizing the Cooperative Advantage at the Atkinson Housing Cooperative: The Role of Community Development to Improve Public Housing." Journal of Entrepreneurial and Organizational Diversity, 4 (1), 52-74.

Southcott, Chris, \& Walker, Valerie. (2015). "A Portrait of the Social Economy in Northern Canada." In Northern Communities Working Together: The Social Economy of Canada's North, Chris Southcott (Ed.). (pp. 21-51). Toronto, ON: University of Toronto Press.

Sterritt, Angela. (2020). "Indigenous Grandfather and 12-Year Old Grand-Daughter Handcuffed in Front of a Vancouver Bank after Trying to Open a Bank Account." CBC, January 9. https://www.cbc.ca/news/canada/british-columbia/indigenous-girl-grandfather-handcuffed-bank1.5419519

Stewart, James. (1984). "Building a Cooperative Economy: Lessons from the Black Experience." Review of Social Economy, 17, 360-68.

Stikeman, Ginny, \& Brand, Dionne. (1991). Sisters in Struggle. 1991. [Film] National Film Board of Canada.

Stopp, M. P. (2014). The Inuit Co-operative Movement in Northern Canada. Montreal International Summit. International Cooperative Alliance. http://ica.coop/en/

St. Pierre, Maurice. (1999). Anatomy of Resistance: Anticolonialism in Guyana 1823-1966. London: MacMillan Education.

Sullivan, Leon. (1969). Build, Brother, Build: From Poverty to Economic Power. Philadelphia: Macrae Smith Co. Publishers.

Sutton, Stacey A. (2019). "Cooperative Cities: Municipal Support for Worker Cooperatives in the United States." Journal of Urban Affairs, 41(8), 1081-1102.

Tadesse, Michael Emru. (2020). The Black Social Economy in Germany: A Study of ROSCAs by Ethiopian Immigrants. MA Thesis, Alice Salomon University, Berlin, Germany.

Thiagarajan, Kamala. (2019). "Millions of Women in India Join Hands to Form A 385-Mile Wall of Protest." NPR Radio, 4 January.

Thomas, C. Y. (1974). Dependency and Transformation: The Economics of the Transition to Socialism. New York: Monthly Review Press.

Thomas, C. Y. (1988). The Poor and the Powerless: Economic Policy and Change in the Caribbean. New York: Monthly Review Press.

Timothy, Roberta K. (2018.) “How Racism Impacts Your Health." Section: Society. Maclean's, March 1. https://www.macleans.ca/society/how-racism-impacts-your-health/

Toney, Jared. (2010). “Locating Diaspora: Afro-Caribbean Narratives of Migration and Settlement in Toronto, 19141929." Urban History Review/Revue d'histoire urbaine, 38 (2), 75-87.

Tulugak, Aliva, \& Murdoch, Peter. (2007). A New Way of Sharing: A Personal History of the Cooperative Movement in Nunavik. Fédération des coopératives du Nouveau-Québec.

Vezina, M., Malo, M-C., \& Ben Selma, M. (2017). "Mature Social Economy Enterprise and Social Innovation: The Case of the Desjardins Environmental Fund." Annals of Public and Cooperative Economics, 88 (2), 257-78. 
Wade, M, Linton, D., \&Sharma, V. (1984). "Off Campus: Developing Co-operative Housing for Students." Occasional Paper No. 8, Institute of Urban Studies, University of Winnipeg,

Washington, Booker T. (2013[1901]). Up from Slavery: An Autobiography. Delhi, India: Ratna Sagar Press Ltd.

Wawanesa Mutual Insurance Company [website]. (1996-2020). "History of Wawanesa." https://www.wawanesa.com/canada/about-us/about-history.html

Welton, Michael R. (2003). "Decoding Coady: Masters of Their Own Destiny under Critical Scrutiny." Studies in Continuing Education, 25 (1), 75-93.

Williams, Chancellor. (1993) [First published in 1967]. "The Economic Basis of African Life," In the Rebirth of African Civilization. Chicago: Third World Press.

Williams, Richard C. (2007). The Cooperative Movement: Globalization from Below. Farnham, UK: Ashgate Publishers.

Williams, Richard C. (2010). The Cooperative Solution: Toward a Just Economy. Lanham, MD: University Press of America.

Winks, Robin W. (1997). The Blacks in Canada: A History. Toronto, ON: McGill-Queen's University Press.

Wuttunee, Wanda A. (1992). "Ikaluktutiak Co-operative Limited, Cambridge Bay, NWT." In Business for Ourselves: Northern Entrepreneurs, 79-100. Kingston, ON: McGill-Queen's Press,

Wuttunee, Wanda A. (2009). "Aboriginal Perspectives on the Social Economy." Living economics: Canadian Perspectives on the Social Economy, Co-operatives, and Community Economic Development. Toronto, ON: Emond Montgomery Publications.

Wuttunee, Wanda A. (2010). Living Rhythms: Lessons in Aboriginal Economic Resilience and Vision. Kingston, ON: McGill-Queens University Press.

Yasmeen, Gisele. (1993). Mutual Aid Networks in Two Feminist Housing Co-operatives in Montreal, Quebec. Master's Thesis, McGill University.

Yee, Shirley J. (1994). "Gender Ideology and Black Women as Community-Builders in Ontario, 1850-70." Canadian Historical Review, 75 (1), 53-73.

\section{Notes}

${ }^{1}$ I use Joseph Mensah's (2010) definition of Black in Black Canadians.

${ }^{2}$ See more about the Underground railroad at The Harriet Tubman Historical Society website: http://www.harriettubman.org/

${ }^{3}$ A publication focused on the theory of CY Thomas in Canada's economic development sector is forthcoming.

${ }^{4}$ Term first coined by the late Bajan scholar Kamau Brathwaite (1981) and also used in Tiffany Lethabo King's recent work (2019) in The Black Shaols.

${ }^{5}$ This article is guided by the ideas of economist C.Y. Thomas at the University of Guyana in the Institute of Development Studies program who mentored my doctoral field work in 2010. 